\title{
Effects of Perinatal Factors on Platelet Indices in Late Preterm and Term Newborns
}

\section{Geç Preterm ve Term Yenidoğanlarda Perinatal Faktörlerin Trombosit İndeksleri Üzerindeki Etkileri}

\author{
(1)Nuran Üstün \\ İstanbul Medeniyet University, Goztepe Training and Research Hospital, Department of Pediatrics, Division of Neonatology, İstanbul, Turkey
}

\begin{abstract}
Aim: This study aimed to compare platelet indices between late preterm and term newborns, and to analyze their relationship with perinatal conditions.
\end{abstract}

Material and Method: Ninety-eight late preterm and 102 term newborns admitted to the neonatal intensive care unit between 2018 and 2020 were retrospectively evaluated. Platelet indices including platelet count (PLT), mean platelet volume (MPV), plateletcrit (PCT), and platelet distribution width (PDW) were measured in blood samples taken on the first day of life.

Results: There was no significant difference in the PLT, MPV, PCT, and PDW values between late preterm and term newborns. In late preterm newborns, multivariable analysis showed that maternal hypertension was significantly related to lower PLT ( $p=0.001)$. In term newborns, multivariable analysis showed that being small for gestational age (SGA), male sex, and maternal hypertension were significantly related to lower PLT $(p<0.001, p=0.001$ and $p=0.017$, respectively). In addition, SGA and male sex were related to lower PCT $(p=0.001)$. In all studied patients, MPV was significantly different between infants with and without prolonged rupture of membrane (PROM) (9.8 fL vs. $9.2 \mathrm{fL}$, $\mathrm{p}=0.001$ ).

Conclusion: The obtained results show that various perinatal features influence the platelet indices in late preterm and term newborns.

Keywords: Platelet indices, late preterm infants, platelet count
Öz

Amaç: Bu çalışmanın amacı geç preterm yenidoğanlar ve term yenidoğanlarda trombosit indekslerini karşılaştırmak ve perinatal faktörlerle ilişkisini incelemektir.

Gereç ve Yöntem: 2018-2020 yılları arasında akademik bir merkezin Yenidoğan Yoğun Bakım Ünitesine kabul edilen 98 geç preterm ve 102 term yenidoğan retrospektif olarak değerlendirildi. Yaşamın ilk gününde alınan kan örneklerinde trombosit sayısı (PLT), ortalama trombosit hacmi (MPV), plateletkrit (PCT) ve trombosit dağılım genişliği (PDW) dahil olmak üzere trombosit indeksleri ölçüldü.

Bulgular: Geç prematüre ve term yenidoğanlar arasında PLT, MPV, PCT ve PDW değerleri açısından anlamlı fark yoktu. Geç prematüre yenidoğanlarda, çok değişkenli analiz, maternal hipertansiyonun düşük PLT ile anlamlı şekilde ilişkili olduğunu gösterdi ( $p=0,001)$. Term yenidoğanlarda, çok değişkenli analiz, gebelik yaşına küçük (SGA) olmak, erkek cinsiyet ve maternal hipertansiyonun düşük PLT ile anlamlı şekilde ilişkili olduğunu gösterdi (sırasıyla $p<0,001, p=0,001$ ve $p=0,017$ ). Ayrıca, SGA ve erkek cinsiyet daha düşük $P C T$ ile ilişkiliydi $(p=0,001)$. Çalışılan tüm hastalarda, MPV, uzamış membran rüptürü (PROM) olan ve olmayan bebekler arasında önemli ölçüde farklıydı ( 9,8 fL ve 9,2 $f L, p=0,001$ ).

Sonuç: Elde edilen sonuçlar, çeşitli perinatal özelliklerin geç preterm ve term yenidoğanların trombosit indekslerini etkilediğini göstermektedir.

Anahtar Kelimeler: Trombosit indeksleri, geç preterm, trombosit sayısı

Corresponding (illetişim): Nuran Üstün, MD, İstanbul Medeniyet University, Goztepe Training and Research Hospital, Department of Pediatrics, Division of Neonatology, İstanbul, Turkey

E-mail (E-posta): nuranustun@yahoo.com

Received (Geliş Tarihi): 12.03.2021 Accepted (Kabul Tarihi): 26.05.2021 


\section{INTRODUCTION}

Platelets have a role in various physiological and pathological process. The main function of platelets is to provide hemostasis, and they also have several immunological functions. ${ }^{[1-3]}$ Platelet indices including total platelet count (PLT), mean platelet volume (MPV), plateletcrit (PCT), and platelet distribution width (PDW) are biomarkers of platelet activation. Platelet production is characterized by proliferation and differentiation of megakaryocytes with stimulation of thrombopoietin. Newborns, particularly preterm newborns have immature platelets. Several studies have shown that platelet count decreases with gestational age and birth weight. ${ }^{[4]}$ Previous research has shown that the risk of thrombocytopenia increases almost 2.5 times in low birth weight infants. ${ }^{[5]}$ Besides, MPV, PCT and PDW have been related to neonatal sepsis and intraventricular hemorrhage..$^{[6,7]}$ Among neonates born $<32$ weeks' gestation, higher MPV has been related with mortality. ${ }^{\left[{ }^{[8]}\right.}$

Late preterm newborns (LPN), born between 34 and 36 weeks of gestation, constitute $75 \%$ of all preterm births, and they are the fastest growing preterm group. ${ }^{[9]}$ Although generally not considered to be high risk, late-preterm infants have increased mortality and morbidity compared to term infants. ${ }^{[10]} \mathrm{A}$ recent study showed reduced PLT and PCT in LPN compared with term newborns (TN). ${ }^{[1]}$ However, studies regarding the impact of perinatal conditions on platelet indices in late preterm and term newborns are limited. Additionally, some studies have found that maternal complications including prolonged rupture of membrane (PROM) and maternal hypertension (HT) can affect platelet indices. ${ }^{[12,14]}$ In this study, we aimed to analyze the relationship between perinatal factors and platelet indices at birth in late preterm and term newborns.

\section{MATERIAL AND METHOD}

This study was approved by Hospital Ethics Committee (No: 2021/0063). Medical records of 1118 newborns admitted to the neonatal intensive care unit of an academic center between January 2019 and December 2020 were retrospectively screened. Of these infants, 98 late preterm and 102 term (born at 37 and 41 weeks of gestation) newborns were included in the study. Exclusion criteria were congenital infections, alloimmune thrombocytopenia, major congenital malformations, metabolic diseases, clinically or laboratory confirmed early onset sepsis, and infants not tested within 6 hours of birth.

Blood samples were obtained from peripheral veins during admission. For each patient, PLT, MPV, PCT, and PDW values were recorded. Patient's demographics including sex, birth weight, mode of delivery, Apgar scores at 5 minutes as well as prenatal factors including maternal HT and PROM were noted. Gestational age was estimated based on the last menstrual period and ultrasound in the first trimester. Small for gestational age (SGA) was defined as birth weight below the 10th percentile according to Fenton growth charts.

\section{Statistical analysis}

Data were analyzed by SPSS version 22 (SPSS Inc., Chicago, IL). Platelet indices were presented as median and interquartile range (IQR) as non-normality of distribution and compared by Mann-Whitney U test. Categorical variables were compared by Chi-squared test. Correlations between platelet indices and gestational age, birth weight and 5 minute Apgar scores were analyzed by using Spearman's rank test. Variables with $p<0.05$ in univariate tests were included in multivariate linear regression. Significance was set at $p<0.05$.

\section{RESULTS}

The median gestational age was 35.4 (IQR: 35-36.2) weeks in late preterm and 38.6 (IQR: 37.6-39.3) weeks in term newborns. Birth weight was 2340.5 (IQR:2020-2765) $\mathrm{g}$ and 2840 (IQR: 2595-3325) $\mathrm{g}$ in late preterm and term newborns, respectively.

Table 1 describes the platelet indices in LPN and TN. There were no significant differences in platelet indices between LPN and TN. No significant correlation was observed between gestational age, birth weight and PLT (Figure 1 and Figure 2).

\begin{tabular}{|c|c|c|c|}
\hline & $\begin{array}{l}\text { Late premature }(n=98) \\
\text { Median (IQR) }\end{array}$ & $\begin{array}{l}\text { Term }(\mathbf{n}=102) \\
\text { Median (IQR) }\end{array}$ & $P$ value \\
\hline GA (weeks) & $35.4(34.6-36.2)$ & $38.8(38-39.3)$ & $<0.001$ \\
\hline BW (grams) & $2340.3(2020-2765)$ & $2840(2595-3325)$ & $<0.001$ \\
\hline SGA, n (\%) & $29(29.6 \%)$ & 20 (19.6\%) & 0.101 \\
\hline PLT $(\times 103 / \mu L)$ & $250(211-326)$ & $262.5(225-309)$ & 0.526 \\
\hline MPV (fL) & $9.3(8.9-9.7)$ & $9.3(9-9.6)$ & 0.674 \\
\hline РCT (\%) & $0.3(0.2-0.3)$ & $0.3(0.2-0.3)$ & 0.372 \\
\hline PDW & $16.3(16.1-16.5)$ & $16.3(16.1-16.4)$ & 0.976 \\
\hline \multicolumn{4}{|c|}{$\begin{array}{l}\text { GA, gestational age; BW, birth weight; PLT, platelet count; MPV, mean platelet volume; } \mathrm{PCT} \text {, } \\
\text { plateletcrit; PDW, platelet distribution width; IQR, median interquartile range, SGA, small for } \\
\text { gestational age. }\end{array}$} \\
\hline
\end{tabular}

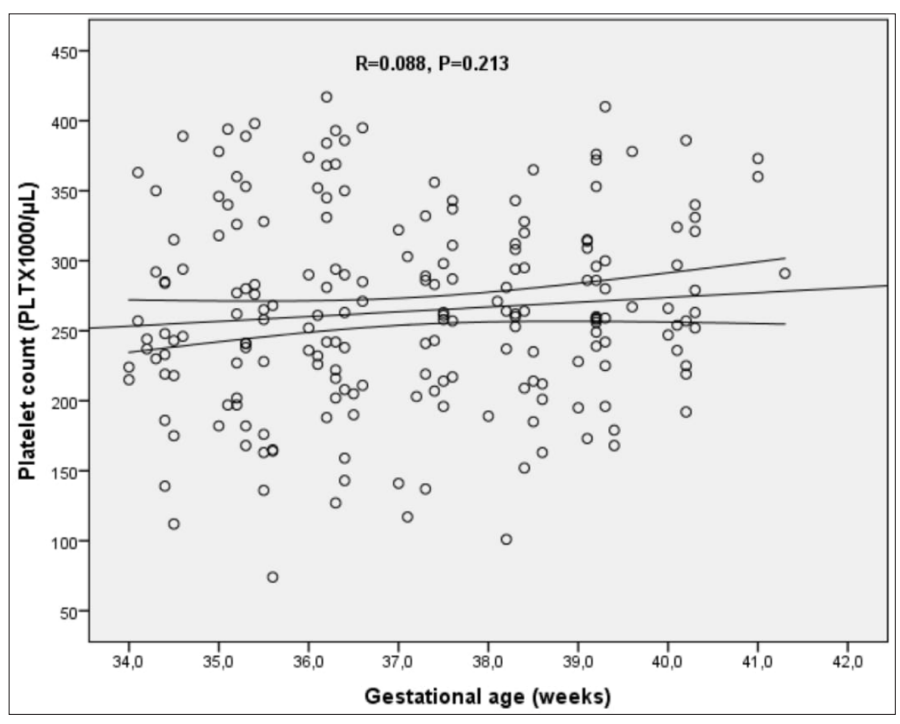

Figure 1. Correlation between platelet count and gestational age. $R$ is Spearman's correlation coefficient. 


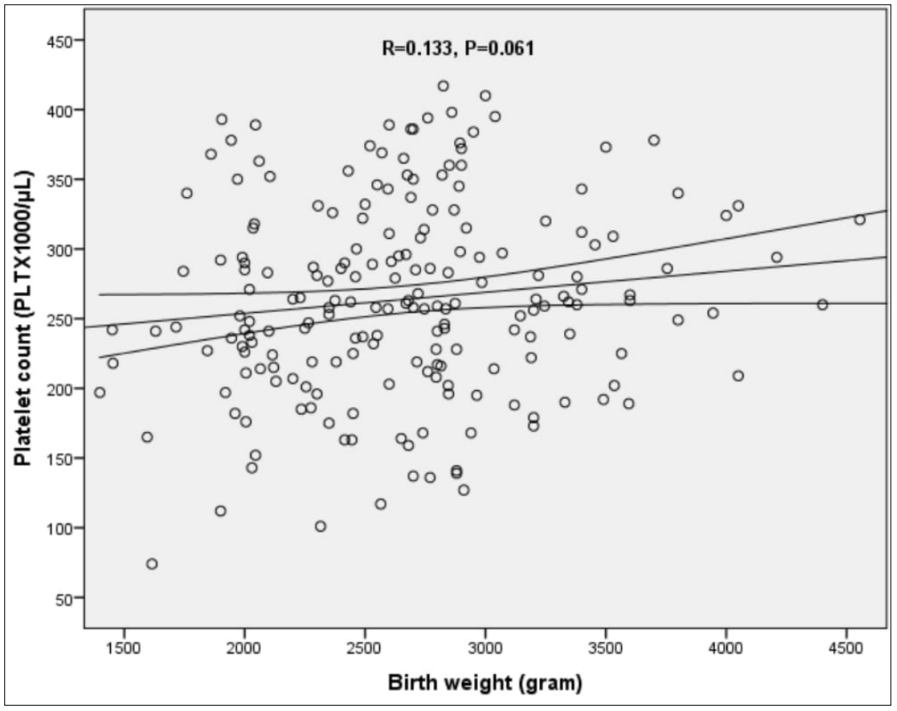

Figure 2. Correlation between platelet count and birth weight. $\mathrm{R}$ is Spearman's correlation oefficient.

Table 2 and Table 3, respectively, describes the platelet indices according to patient's characteristics in late preterm and term newborns. In late preterm newborns, infants of hypertensive mothers showed significantly lower PLT $\left(208 \times 10^{3} / \mu \mathrm{L}\right.$ vs. $\left.265 \times 10^{3} / \mu \mathrm{L}, \mathrm{p}=0.035\right)$ and PCT $(0.2 \%$ vs. $0.3 \%$, $\mathrm{p}=0.047$ ) compared to infants of mothers without $\mathrm{HT}$. Infants born by cesarean section had a lower PLT $\left(236.5 \times 10^{3} / \mu \mathrm{L}\right.$ vs. $272.5208 \times 10^{3} / \mu \mathrm{L}, \mathrm{p}=0.031$ ). Compared to non-SGA infants, SGA infants presented lower PLT $\left(203 \times 10^{3} / \mu \mathrm{L}\right.$ vs. $263 \times 10^{3} /$ $\mu \mathrm{L}, \mathrm{p}=0.030)$ and $\mathrm{PCT}(0.2 \%$ vs. $0.2 \%, \mathrm{p}=0.033)$. Multivariate analysis revealed that Maternal $\mathrm{HT}$ was significantly related to lower PLT $(\beta=-0.336, p=0.001)$ while no factors related to PCT and PDW were found.
In term newborns, males presented lower PLT $\left(258 \times 10^{3} / \mu \mathrm{L}\right.$ vs. $277 \times 10^{3} / \mu \mathrm{L}, \mathrm{p}=0.013$ ) compared to female newborns. Multivariate analysis showed that being SGA $(\beta=-0.377$, $p<0.001)$, male sex $(\beta=-0.281, p=0.001)$ and maternal HT ( $\beta=-0.209, p=0.017$ ) were significantly related to lower PLT. In addition, SGA $(\beta=-0.401, p=0.001)$ and male sex $(\beta=-0.307$, $p=0.001)$ were associated with lower PCT.

In all studied patients, MPV was significantly different between infants with and without PROM ( $9.8 \mathrm{fL}$ vs. $9.2 \mathrm{fL}, \mathrm{p}=0.001$ ).

\section{DISCUSSION}

This study demonstrated that platelet indices did not differ between late preterm and term newborns. Previous studies reported that LPN present lower PLT and PCT compared to TN. ${ }^{[11,15]}$ Alicja et al. ${ }^{[1]]}$ evaluated platelet parameters of $71 \mathrm{TN}$ and 58 LPN and found that PLT correlated with gestational age and birth weight. In our study, there was no correlation between PLT and gestational age or birth weight. On the other hand, Rolim et al. ${ }^{[16]}$ evaluated hematologic profile in 2662 newborns including 193 late preterm, and showed that platelets remained nearly constant during gestation. These variations can be explained by differences in patient characteristics and sample size.

The present study demonstrated that various patient's characteristics have an impact on platelet indices in late preterm and term newborns. Term SGA newborns showed lower PLT and PCT than non-SGA infants, as previously reported. ${ }^{[17-19]}$ Reduced platelet count indicates the immaturity of platelet production in SGA newborns. ${ }^{[20]}$ Thrombopoietin, the main regulator of platelet production, is produced by liver. The original location of fetal thrombopoiesis is the

\begin{tabular}{|c|c|c|c|c|}
\hline Maternal HT (15) & $208(165-238)$ & $9.6(8.7-9.8)$ & $0.2(0.1-0.25)$ & $16.4(16.2-16.6)$ \\
\hline non-maternal HT (83) & $P=0.035$ & $P=0.790$ & $P=0.047$ & $P=0.451$ \\
\hline PROM (23) & $239.5(208-283)$ & $9.75(9-10.5)$ & $0.2(0.2-0.3)$ & $16.4(15.9-16.6)$ \\
\hline non-PROM (75) & $257.5(217-335.5)$ & $9.2(8.9-9.6)$ & $0.2(0.2-0.3)$ & $16.3(16.1-16.5)$ \\
\hline \multirow[t]{2}{*}{ Vaginal delivery (32) } & $272.5(236.5-351.5)$ & 9.25 (8.9-9.75) & $0.2(0.2-0.3)$ & $16.2(16-16.45)$ \\
\hline & $P=0.031$ & $P=0.693$ & $P=0.068$ & $\mathrm{P}=0.128$ \\
\hline Male (54) & $237.5(187.7-293.3)$ & $9.2(8.8-9.7)$ & $0.2(0.2-0.3)$ & $16.3(16.1-16.5)$ \\
\hline \multirow[t]{2}{*}{ Female (44) } & $261.5(219.5-310.7)$ & $9.2(8.7-9.7)$ & $0.2(0.2-0.3)$ & $16.3(16.1-16.5)$ \\
\hline & $P=0.123$ & $P=0.694$ & $P=0.131$ & $P=0.755$ \\
\hline SGA (29) & $203(159-221.5)$ & $9(8.8-9.5)$ & $0.2(0.1-0.2)$ & $16.2(16-16.4)$ \\
\hline \multirow{2}{*}{ Birth weight } & $r=0.206$ & $r=-0.120$ & $r=0.219$ & $r=-0.096$ \\
\hline & $P=0.042$ & $P=0.238$ & $P=0.031$ & $P=0.347$ \\
\hline \multirow{2}{*}{5 min Apgar score } & $r=0.123$ & $r=-0.136$ & $r=0.061$ & $r=-0.127$ \\
\hline & $P=0.226$ & $P=0.182$ & $P=0.0 .552$ & $P=0.213$ \\
\hline
\end{tabular}




\begin{tabular}{|c|c|c|c|c|}
\hline Factor (n) & 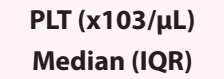 & $\begin{array}{c}\text { MPV (fL) } \\
\text { Median (IQR) }\end{array}$ & $\begin{array}{c}\text { PCT (\%) } \\
\text { Median (IQR) }\end{array}$ & $\begin{array}{c}\text { PDW } \\
\text { Median (IQR) }\end{array}$ \\
\hline Maternal Ht (6) & $211(163-266)$ & $9.3(8.6-9.9)$ & $0.2(0.2-0.2)$ & $16.3(161-16.4)$ \\
\hline \multirow[t]{2}{*}{ Non-maternal HT (96) } & $265(236-313.5)$ & $9.3(9-9.6)$ & $0.2(0.2-0.3)$ & $16.3(16.1-16.5)$ \\
\hline & $P=0.011$ & $\mathrm{P}=0.928$ & $P=0.037$ & $P=0.874$ \\
\hline PROM (7) & $283(231-328)$ & $9.9(9.3-10.3)$ & $0.3(0.2-0.3)$ & $16.5(16.2-16.6)$ \\
\hline \multirow[t]{2}{*}{ Non-PROM (95) } & 263 (226.5-299) & $9.2(9-9.6)$ & $0.3(0.2-0.3)$ & $16.3(16.1-16.4)$ \\
\hline & $P=0.385$ & $P=0.014$ & $P=0.176$ & $P=0.085$ \\
\hline Cesarean delivery (66) & $260(237-299)$ & $9.15(8.5-9.6)$ & $0.2(0.2-0.3)$ & $16.3(16.1-16.5)$ \\
\hline \multirow[t]{2}{*}{ Vaginal delivery (36) } & $286(243.7-318)$ & 9.05 (8.7-9.3) & $0.3(0.2-0.3)$ & $16.3(16-16.4)$ \\
\hline & $P=0.167$ & $P=0.577$ & $P=0.313$ & $P=0.358$ \\
\hline Male (52) & $258(221-286.5)$ & $9.3(9-9.75)$ & $0.2(0.2-0.3)$ & $16.3(16.1-16.5)$ \\
\hline \multirow[t]{2}{*}{ Female (50) } & $277(236-332)$ & $9.2(9-9.6)$ & $0.2(0.2-0.3)$ & $16.25(16.1-16.4)$ \\
\hline & $P=0.013$ & $P=0.673$ & $P=0.009$ & $P=0.069$ \\
\hline SGA (20) & $210.5(185-247)$ & $9.2(9-9.5)$ & $0.2(0.2-0.2)$ & $16.3(16-16.4)$ \\
\hline \multirow[t]{2}{*}{ Non-SGA (82) } & $278.5(239-317.5)$ & $9.3(9-9.7)$ & $0.3(0.2-0.3)$ & $16.3(16.1-16.5)$ \\
\hline & $P<0.001$ & $P=0.297$ & $P=0.004$ & $P=0.980$ \\
\hline \multirow{2}{*}{ Gestational age } & $r=0.134$ & $r=-0.061$ & $r=-0.153$ & $r=-0.002$ \\
\hline & $P=0.180$ & $P=0.540$ & $P=0.112$ & $P=0.984$ \\
\hline \multirow{2}{*}{ Birth weight } & $r=0.170$ & $r=0.064$ & $r=0.170$ & $r=-0.086$ \\
\hline & $P=0.087$ & $P=0.525$ & $P=0.088$ & $P=0.391$ \\
\hline \multirow{2}{*}{5 min Apgar score } & $r=0.170$ & $r=-0.076$ & $r=0.143$ & $r=-0.095$ \\
\hline & $P=0.088$ & $P=0.477$ & $P=0.152$ & $P=0.344$ \\
\hline
\end{tabular}

liver and spleen. ${ }^{[21]}$ Intrauterine growth restriction disturbs the development of internal organs as a result of the redistribution of blood to the brain. Hiett et al. ${ }^{[22]}$ reported that SGA infants had fewer circulating megakaryocytes in cord blood. Moreover, in present study, infants born to mothers with hypertension showed lower PLT and PCT. Maternal hypertension has been reported to be associated with neonatal thrombocytopenia. ${ }^{[12,23]}$ Although the pathogenesis of neonatal thrombocytopenia in maternal hypertension is not well-established, one potential mechanism is that chronic fetal hypoxia caused by maternal hypertension may impair megakaryocyte proliferation. ${ }^{[24]}$

This study showed that MPV was high in newborns born from pregnancies with PROM. Chen et al. ${ }^{[25]}$ found that MPV correlates with intrauterine infection in newborns with combined leukopenia and thrombocytopenia. MPV was also associated with the development of intracranial hemorrhage, chronic lung disease and necrotizing enterocolitis in preterm very low birth weight infants. ${ }^{[26]}$ High MPV and PDW values were reported in late neonatal sepsis. ${ }^{[27]}$ In this study, there was no case diagnosed with late sepsis.

We also found that term male newborns present lower platelet values. Though studies on the relationship between sex and PLT are very limited, a previous study ${ }^{[28]}$ reported higher PLT in females compared to males in full term infants. However, the mechanism of PLT changes by sex are not clearly established. Some researchers suggested that males may have a restricted maturity of thrombopoiesis. ${ }^{[15]}$ Several studies reported a significant relationship between low Apgar scores and thrombocytopenia. ${ }^{[29,30]}$ In a study of preterm infants between 27 and 35 weeks of gestation, Beiner et al. ${ }^{[31]}$ found that lower gestational age, low 5 min Apgar, SGA, and cesarean delivery were risk factors for neonatal thrombocytopenia. In a murine model, severe hypoxia was shown to be related to shortened platelet survival. ${ }^{[32]}$ In our study, there was no relationship between platelet indices and 5 minute Apgar scores. This might be due to the small number of cases with severe birth asphyxia in our study population.

This study has certain limitations. Given the retrospective nature of this study, the timing of blood samples was not sufficiently standardized which might affect platelet indices. Additionally, this was a single-center study involving a small sample size, which limits to generalize available results to other centers. Also, term infants in our study had various complications such as hypoglycemia or transient tachypnea of the newborns. The blood samples should have been collected from healthy term infants for comparison of platelet indices between late preterm and term newborns.

\section{CONCLUSION}

The present study shows that several perinatal conditions influence the platelet indices in late preterm and term newborns. Particularly, SGA, maternal hypertension, and male sex were related to reduced PLT and PCT. Moreover, MPV was found to be associated with PROM. Thus, it is important to evaluate platelet parameters in newborns with different perinatal factors since these neonates might have 
impaired platelet parameters which could lead to hemostatic disorders and infectious diseases. Further studies regarding the consequences of late prematurity and perinatal factors on platelet indices are required.

\section{ETHICAL DECLARATIONS}

Ethics Committee Approval: Medeniyet University Goztepe Training Hospital Ethics Committee (No: 2021/0063).

Informed Consent: Because the study was designed retrospectively, no written informed consent form was obtained from patients.

Referee Evaluation Process: Externally peer-reviewed.

Conflict of Interest Statement: The author(s) declared no potential conflicts of interest with respect to the research, authorship, and/or publication of this article.

Financial Disclosure: The authors declared that this study has received no financial support.

Author Contributions: All of the authors declare that they have all participated in the design, execution, and analysis of the paper, and that they have approved the final version.

\section{REFERENCES}

1. Golebiewska EM, Poole AW. Platelet secretion:From haemostasis to wound healing and beyond. Blood Rev 2015;29:153-62.

2. Coban $E$, Adanir H, Bilgin D. The association of mean platelet volume levels with hypertensive retinopathy. Platelets. 2008;19(2):115-8.

3. Martin JF, Kristensen SD, Mathur A, Grove EL, Choudry FA. The causal role of megakaryocyte-platelet hyperactivity in acute coronary syndromes. Nat Rev Cardiol. 2012;9(11):658-70.

4. Wiedmeier SE, Henry E, Sola-Visner MC, Christensen RD. Platelet reference ranges for neonates, defined using data from over 47,000 patients in a multihospital healthcare system. J Perinatol 2009;29:130-6.

5. Roberts I, Murray NA. Neonatal thrombocytopenia:causes and management. Arch Dis Child Neonatal Ed. 2003;88:F359-64.

6. Aydemir C, Aydemir H, Kokturk F, Kulah C, Mungan AG. The cut-off levels of procalcitonin and $C$-reactive protein and the kinetics of mean platelet volume in preterm neonates with sepsis. BMC Pediatr. 2018;18(1):253

7. Mitsiakos G, Papathanasiou AE, Kyriakidis I, et al. Intraventricular Hemorrhage and Platelet indices in Extremely Premature Neonates. J Pediatr Hematol Oncol. 2016;38(7):533-8.

8. Go $\mathrm{H}$, Ohto $\mathrm{H}$, Kenneth $\mathrm{N}$, et al. Using Platelet Parameters to Anticipate Morbidity and Mortality Among Preterm Neonates:A Retrospective Study. Front Pediatr.2020;8:90

9. Loftin RW, Habli M, Snyder CC, et al. Late preterm birth. Rev Obstet Gynecol 2010;3 :10-19.

10. Meloni A, Antonelli A, Deiana S, et al. Late preterm:obstetric management. J Matern Fetal Neonatal Med 2010;23:113-5.

11. Alicja W, Agnieszka P, Piotr L, et al. Platelet indices in late preterm newborns. J Matern Fetal Neonatal Med. 2017;30(14):1699-703.

12. Backes CH, Markham K, Moorehead P, Cordero L, Nankervis CA, Giannone PJ. Maternal preeclampsia and neonatal outcomes. J Pregnancy $2011 ; 214365$

13. Thalor N, Singh K, Pujani M, Chauhan V, Agarwal C, Ahuja R. A correlation between platelet indices and preeclampsia. Hematol Transfus Cell Ther. 2019;41(2):129-33.

14. Ekin A, Gezer C, Kulhan G, Avci ME, Taner CE. Can platelet count and mean platelet volume during the first trimester of pregnancy predict preterm premature rupture of membrenes? J Obstet Gynaecol Res 2015;41(1):238.
15. Wasiluk A, Osada J, Dabrowska M, Szczepański M, Jasinska E. Does prematurity affect platelet indices? Adv Med Sci. 2009;54(2):253-5.

16. Rolim ACB, Lambert MA, Borges JPG, et al. Blood Cells Profile In Umbilical Cord Of Late Preterm And Term Newborns. Revista Paulista de Pediatria, 2019;37(3):264-74.

17. Christensen RD, Baer VL, Henry E, Snow GL, Butler A, Sola-Visner MC. Thrombocytopenia in Smallfor- Gestational-Age Infants. Pediatrics. 2015;135(2):e361-70.

18. Fustolo-Gunnink SF, Vlug RD, Smits-Wintjens VE, et al. Early-Onset Thrombocytopenia in Small-For-Gestational-Age Neonates:A retrospective Cohort Study. PLoS One. 2016;11(5):e0154853.

19. Lee E, Lim Z, Malhotra A. Thrombocytopenia in well small for gestational age neonates. Blood Coagul Fibrinolysis. 2019. 30(3):104-10.

20. Wasiluk A, Mantur M, Kemona H, Szczepański M, Jasińska E, Milewski R. Thrombopoiesis in small for gestational age newborns. Platelets. 2009;20(7):520-4.

21. Liu Z-J, Sola-Visner M. Neonatal and adult megakaryopoiesis. Curr Opin Hematol 2011;18:330-7.

22. Hiett AK, Britton KA, Hague NL, Brown HL, Stehman FB, Broxmeyer HE. Comparison of hematopoietic progenitor cells in human umbilical cord blood collected from neonatal infants who are small and appropriate for gestational age Transfusion. 1995;35 (7) pp. 587-91.

23. Brazy JE, Grimm JK, Little V. A. Neonatal manifestations of severe maternal hypertension occurring before the thirty-sixth week of pregnancy. J Pediatr. 1982;100(2):265-71.

24. Weiner C. P. and Williamson R. A. Evaluation of severe growth retardation using cordocentesis - hematologic and metabolic alterations by etiology. Obstet Gynecol.1989;73(2):225-9.

25. Chen CY, Essien MD, Johnson AJ, Lee GT, Chou FS. Use of mean platelet volume in the assessment of intrauterine infection in newborns with thrombocytopenia and leukopenia at birth. J Matern Fetal Neonatal Med. 2019;1-7

26. Cekmez F, Tanju IA, Canpolat FE, et al. Mean platelet volume in very preterm infants:a predictor of morbidities? Eur Rev Med Pharmacol Sci 2013;17:134-7

27. Patrick $\mathrm{CH}$, Lazarick J. The effect of bacteremia on automated platelet measurements in neonates. Am J Clin Pathol 1990;93:391-4.

28. Wasiluk A. Thrombocytopoiesis in healthy term newboms. J Perinat Med. 2005;33(3):252-4.

29. Saxonhouse MA, Rimsza LM, Stevens G, Jouei N, Christensen RD, Sola MC. Effects of hypoxia on megakaryocyte progenitors obtained from the umbilical cord blood of term and preterm neonates. Biol Neonate. 2006;89(2):104-8

30. Nadkarni J, Patne SK, Kispotta R. Hypoxia as a predisposing factor for the development of early onset neonatal thrombocytopenia. J Clin Neonatol. 2012;1(3):131-4.

31. Beiner ME, Simchen MJ, Sivan E, Chetrit A, Kuint J, Schiff E. Risk factors for neonatal thrombocytopenia in preterm infants. Am J Perinatol. 2003;20(1):49-54.

32. Castle V, Coates G, Mitchell LG, O'Brodovich H, Andrew M. The effect of hypoxia on platelet survival and site of sequestration in the newborn rabbits. Thromb Haemost. 1988;59(1):45-8. 